\title{
Lycophron: a Minor Sophist or a Minor Socratic?
}

\author{
Stefania Giombini
}

University of Girona

Keywords: Lycophron, Minor Sophists, Minor Socratics, Ancient Social Contract

\section{Foreword}

Gregory Vlastos (1907-1991) ${ }^{1}$ was one of the greatest innovators in the studies of ancient philosophy, a scholar capable of changing methods and attitudes, a model of reference around the world for scholars who have taken his style and approach. In 2014 I have been able to frequent the Harry Ransom Center of the University of Texas at Austin -HRC- ${ }^{2}$ to study Vlastos' work and personal materials in The Vlastos Archive. The archive is a variegated and pluri-thematic fund: firstly, I focused on Vlastos' correspondence (especially the one with Italian scholars). This way, I could suddenly ascertain how the size of Vlastos as a researcher and human being was thick: he interacted with energy and interest with every interlocutor, and those closer to him and those unknown, meticulously preserving even small fragments with names, letters and so on, to avoid losing data and keep memory of everything. Subsequently, extending our investigation to the rest of the archive, an immense amount of notes, books with references, glosses and underlines. While reading the notes I ran across some pages, typewritten, dedicated to the contract theory in Glaucon, Protagoras, Antiphon (obviously including the positions of Plato and Socrates. $)^{3}$ The pages are not dated, and they get into the themes of social contract and justice. Reading these notes he made me rediscover a minor author of Ancient Philosophy: Lycophron. The following work is born on the interest generated by these readings, from an approach towards the private world of Gregory Vlastos.

\section{Who was Lycophron?}

In the list of the authors of the sophistic movement, it can be possible to find some of them that are known as fundamental, and not just in the history of rhetorics but also in the history of philosophy: for instance, Protagoras, Gorgias or Antiphon are known for their

\footnotetext{
${ }^{1}$ For the biography of Gregory Vlastos, see A.P.D. Mourelatos, Gregory Vlastos $†$, «Gnomon» 65, 1993, 378-382; Donalds Davidson - John Ferrari, Biographical Memoirs. Gregory Vlastos, «Proceedings of American Philosophical Society» vol. 148, 2, 2004, 256-259.

2 The HRC (formerly Humanities Reserch Center) is a research center founded in 1957 whose mission is to collect manuscripts and original material in the arts and humanities (http://www.hrc.utexas.edu). The Vlastos Archive was inaugurated on May 24, 2007 and is open for consultation. I thank prof. Alexander P.D. Mourelatos for making my stay possible as a Visiting Scholar at the University of Texas at Austin and the entire University for welcoming me and having facilitated my research.

${ }^{3}$ Vlastos' clipboard: «The theory [of the contract] is sketched briefly, but with remarkable lucidity and attention to the vital points, in Glaucon's speech at the start of R. II. It is a useful introduction to the extant fragments of Antiphon's ON TRUTH, where such a theory is clearly presupposed [...]»; and also, to the theory of Thrasymachus and Callicles' one in the Gorgias. The theme is in part in Vlastos 1973, particularly in the essay "Justice and Happiness in the Republic," 111-139.
} 
contribution to the Greek thought, although not so much of their work has reached us. In the case of Lycophron the situation is even worse, and our first requirement is to try and figure out who he really was.

Lycophron, according to the tradition, was a Minor Sophist, from the second generation, probably active in Athens. Lycophron is considered a pupil of Gorgias: this is not attested in the ancient sources, but the critical literature believed to have established valid considerations for this acknowledgement, thus making the teacher-student relationship between Gorgias and Lycophron a locus communis ${ }^{4}$. The setting of this locus is mainly due to Eduard Zeller in his A History of Greek Philosophy, in the second volume edited in $1881^{5}$. Here Zeller, relying on Aristotle Rhetorica ${ }^{6}$ and Alexander of Aphrodisias, ${ }^{7}$ believed that in these removes it was emphasized how the style of Lycophron demonstrated the fact that he was a pupil of Gorgias.

In the Rhetoric III, 3 -particularly in 1405b 34 and 1406- Aristotle deals with the style of the lyrics and performs an analysis of the instruments that make a style cold, though poetic at the same time: it is a precise context that therefore requires equally precise references. According to Aristotle, the frigidities are caused by four factors: the compound words, the glosses (i.e. words that appear in a specific context or unusual as they come from other dialects or other languages), the epithets and, finally, the metaphors. In order to demonstrate how these factors can generate frigidities, Aristotle brings examples. For the compoud words, he quotes the words of - in order - Lycophron, Gorgias and Alcidamas: of course this is very useful for us since, in the case of Lycophron, these are the only original words that we have. According to Aristotle, Lycophron used the following forms as cases of compound words: "the many-visaged sky of the mighty-peaked earth" (

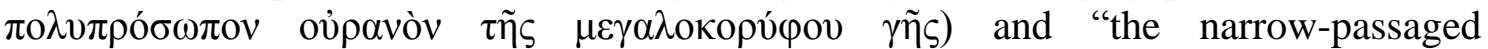

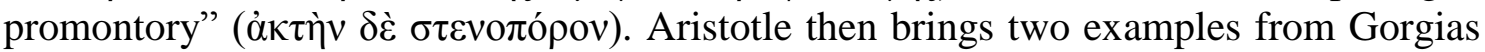
and four from Alcidamas. Besides compound words, frigidities can even be caused by glosses, and Aristotle quotes Lycophron, as he would have called Xerxes "a monster of a

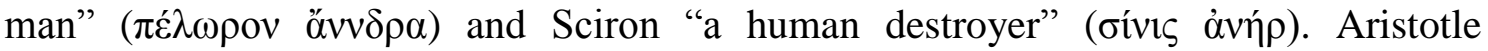
subsequently quotes two samples from Alcidamas. The third cause of frigidities would be the epithets, for which he only quotes Alcidamas. The fourth cause is the metaphors: to this purpose, Aristotle quotes Gorgias and Alcidamas. In the end, Aristotle cites Lycophron's expressions for what concerns compound words and glosses, and he recalls him along with Gorgias and Alcidamas: their style would be close, very close for what concerns the usage of rhetorical tools that make the speech cold. Therefore, if Lycophron was a pupil of Gorgias, Aristotle could cite Gorgias formerly and then Alcidamas and Lycophron, thus maintaining the order for which students follow the teacher. Subsequently Aristotle does so, putting Alcidamas always after Gorgias. It is a small but not so useless element. The Aristotelian text, besides not saying anything about this possbile bond (although in this context it was not necessary at all), is not paying attention to a possible "hierarchy" that privileges the teacher over the alleged student.

There is also another passage in the Rhetoric that refers to such a Lycophron: in the third book 1410, 18, in the context of the discussion of the antithesis. Here Aristotle, without any doubt, does not refer to our intellectual but to the tyrant of Pherae, the second Lycophron who reigned in the fourth century. It is actually a sentence pronounced by an

\footnotetext{
${ }^{4}$ Giannantoni speaks of locus communis also regarding the alleged teacher-pupil relationship between Gorgias and Antisthenes. The fact that Antisthenes has at first listened to Gorgias and then become a student of Socrates is not so relevant as to imply a teacher-pupil relationship. See Giannantoni 1983-85, 204.

${ }^{5}$ Zeller 1881, 425 n. 3.

${ }^{6}$ Rhet. III, 3

${ }^{7}$ Alex. Aphr. in Top. 209, 222: see Zeller 1881, 425 n. 3
} 
unknown (Aristotle does not specify, probably because he does not know his name) against Lycophron and Peitholaus in court: «And [another example of antithesis is] what someone said to Peitholaus and Lycophron in the law court: "When these men were at home, they sold you, but coming to you now they have bought you." ${ }^{8}$ The event must be contextualized in the action committed by Lycophron and Peitholaus who murdered Alexander of Pherae in $358 \mathrm{BC}$ in order to take over. ${ }^{9}$ So there are two Lycophrons in the Rhetoric: an intellectual and a tyrant. Another stance was the one of R.G. Boehnecke ${ }^{10}$, who believed that all references to Lycophron in the work of Aristotle were always to refer to the tyrant. According to Boehnecke, the tyrant would have had a tendency to art and rhetorics and he would have been one tyrant-rhetorician from the half of the fourth century. Boehnecke's conjecture has got some advantages: he manages to locate Lycophron in space and time, assigning him a historical role, and he is far away from what would then be the locus communis for which Lycophron would have been a pupil of Gorgias. But the theory is weak. A little later, Vahlen ${ }^{11}$, in response to Boehnecke and following the revaluation of the ps-Alexander commentary on Sophistical Refutations ${ }^{12}$, excludes that they could be a single person, and instead says that the two references are distinct. ${ }^{13}$ Vahlen's position is definitely the most correct one. In fact in the first quote, in 1405-6, Aristotle certainly refers to an intellectual while in the second excerpt, in 1410a18, he definitely does not. Thereby, Aristotle gives a sentence not directly attributable to Lycophron but said to come from "someone" who spoke in court against Lycophron and Peitholaus: the tyrant of Pherae is singled out, but as an object of the statement and not as its subject. So we shall conclude that in this passage the reference is to the tyrant and, likewise, we shall exclude that the tyrant has had some attitude to rhetorics.

Another possible interesting source for the purpose of reconstructing Lycophron's identity is Plato. In his Letter II, Plato mentions only once someone named Lycophron (314c-d). Plato writes Dionysius about some Lycophron who stayed at his place, along with Polyxenus (about whom we know nothing), sent by Plato, probably to stand by him. But what Dionysius are we talking about? Dionysius I or II? A careful reading of the Letter II still brings many doubts of interpretation that we hereby report in a note ${ }^{14}$, and

\footnotetext{
${ }^{8}$ Kennedy 2007, 216.

${ }^{9}$ Lycophron, Peitholaus (or Pytholaus) and Tisiphonus murdered Alexander, their brother-in-law, as they were brothers of his wife, Thebe; see D.S. XVI, 14.

${ }^{10}$ Boehnecke 1864, 35-41.

${ }^{11}$ Vahlen 1866.

12 Soph. El. 15, 174 b 30-33 (= DK83A6).

13 See Vahlen 1866 and Narcy 2005, 204.

14 Almost all the critical literature I examined states that Plato's Letter II was addressed to Dionysius II (except, e.g. Findlay 1994, 268-269, who argues that the recipient is Dionysius I). We take the chronological coordinates as a premise: the kingdom of Dionysius I places itself in the years 430-367, that of Dionysius II in the years 367-357 (and subsequently 347-344), and Plato went to Sicily for the first time in 388 . The element favouring the hypothesis that the Dionysius in point would actually be the II is the figure of such Archedemus (which is discussed in the Letter VII) that guarantees the relationship between the sovereign and Plato after the philosopher is back in Athens after the first trip to Syracuse. Also in the Letter II, the same Dionysius distrusts Plato and his students so much that he does not want them to stick their nose in his business, while he still trusts Dion. We know that the relationship between Dion and Dionysius II deteriorates early (during the first year of kingdom of the sovereign), then the letter would be placed in this specific period of time: the reign of Dionysius II before the breakup with Dion (about 367). But this would not match with what we know of the relationship between Plato and Dionysius II: while in fact it is true that Plato had bad relations with Dionysius I, given the stormy return to Athens he causes the philosopher (at least according to Diogenes Laertius), it was not the same, however, with Dionysius II, who sent him to Athens with the excuse of the war and, with some diplomacy, kept him on hold for a possible return. In the letter Plato also refers to the fact that Dionysius is concerned that Athens will speak ill of him (and Plato
} 
the only conclusion we can achieve as an insurmountable precondition is that Letter II is an unreliable text, being spurious ${ }^{15}$. We can paradoxically admit the Letter's reliability in any case: what information do we have about this Lycophron? None. It is just a written name: a quite widespread name, moreover, one commonly used ${ }^{16}$. Either way you look Letter II, it is irrelevant to our purpose: it is not a source to know something about Lycophron, not even to place it in space and time.

We can examine the last remarkable note to determine what information is useful to reconstruct a profile of Lycophron: the use of the term "sophist" when talking about him.

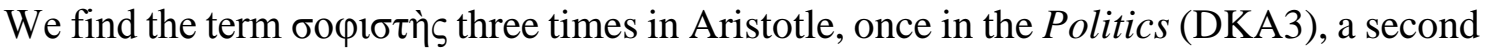
time in fr. 91 Rose On nobility (DKA4) from Stobeus, and a third time in Alexander of Aphrodisias (DKA1): what kind of information does it give to us? Does the usage of this epithet tell us with a certain degree of confidence that we are talking about a member of the sophistic movement? I account as a good comparison basis Gagarin's reflection

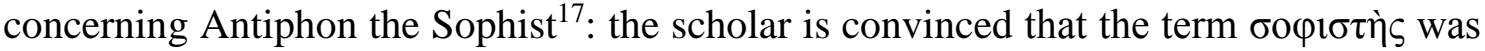
a generic term that could mean only an intellectual activity, and that ultimately did not have, in context, the purpose to distinguish the Sophist from the Rhamnusian, but rather to distinguish the Rhamnusian who also was a sophist from other Antiphons. Thence the epithet "Sophist" would not strictly account for the profession, for the activity to which the name is associated, but stands as a generic name for the purpose of differentiation from others with the same name. The usage of the term sophist in a broader sense may also be useful for the same Lycophron. Lycophron indeed might have been a wise whose title of sophist emphasized his intellectual activity rather than to designate him as a participant in the sophistic movement in a strict sense.

Likewise, we might argue that the term "sophist" was used, perhaps in a derogatory sense, also to indicate the Megarians and their activities: just look at the information the Laertius ${ }^{18}$ gives in point or pay attention to the fact that among the Megarians was also counted Polyxenus the Sophist ${ }^{19}$, to which Alexander of Aphrodisias ${ }^{20}$ attributed "the third man argument", used by Aristotle to criticize Platonism: he probably was a pupil of Bryson of Achaea ${ }^{21}$ and he criticised Plato's theory as it is in Aristotle ${ }^{22}$ and also as it is recalled in Plato's Parmenides. ${ }^{23}$

After these reflections, we can be able to claim that Zeller's conjecture is not so thick, despite having been a locus communis in the last two centuries. The only certainty of

assures him of the contrary): this would be in line with what we find in D.L. III, 21 about the relationship between Plato and Dionysius I; and yet the letter focuses on the relationship between power and wisdom that are the focus of the dialogue between Dionysius I and Plato as we find in D.L. III, 18. These elements if taken together generate the correct confusion: sometimes we are tempted to think that it could be possible to attribute to the addressee of the letter the identity of Dionysius I, sometimes we are more likely to believe that it could be Dionysius II. The fact is that we cannot make a relevant attribution because whoever wrote the letter did not bother to think of it as addressed to one specific interlocutor of the two.

15 I hoped to find in the Letter II, although spurious, some support, at least in a chronological way: I thank prof. Narcy for wisely dissuading me from believing it was possible. As suggested to me, the letter could belong to a "novel", a text which therefore would have no philological attention: a narrative in which the reality of reference is mixed and definitely does not conform to a specific context.

${ }^{16}$ Among the known or elsewhere cited Lycophrons, besides ours, we find an Homeric character (Il. XV, 530), two tyrants of Pherae between V and IV century and later the Hellenistic poet, author of Alexandra.

${ }^{17}$ Gagarin 2002, 41-43.

${ }^{18}$ D.L. II, 106. On sophistic attitude in Stilpo see II, 113.

${ }^{19}$ About the influence of Megarians "Third man argument" Theory in Aristotle cf. Baeumker 1879.

${ }^{20}$ in Arist. Metaph., p. 84, 16 et seq.

${ }^{21}$ On Bryson see D.L. I, 16; VI, 85; IX, 61.

${ }^{22}$ Metaph. 990b15-17.

${ }^{23}$ Prm. 132a-b, 132d-133a. Cf. Vlastos 1954. 
Zeller is that the stylistic juxtaposition between Lycophron and Gorgias is a really small evidence of the teacher-pupil relationship. Finally, a doubt comes to our minds; we wonder why Plato in its many references to sophistry has never mentioned Lycophron if he was, as traditionally stated, a sophist.

\section{Aristotle as our main Source}

We know that Lycophron is an author who received little attention from both ancient literature and critics, even contemporary ones: the reason for this neglect lies in the scarceness of the sources that reached us, all secondary. Yet, notwithstanding that amount of sources, we have not only the interesting content of these sources, but, and this should be heavily stressed, the excellence of our "informer", Aristotle. In fact, of the six testimonies we can look at as collected in DK, the source on Lycophron is only one, Aristotle, with two further excerpts added: one from Alexander of Aphrodisias' commentary on the Metaphysics, and one from the ps-Alexander's commentary on the Sophistical Refutations.

As a result of the paucity of sources, even the bibliography we have is rather thin, and it generally refers to Lycophron as a Minor Sophist or as interested in the theme of the social contract. Mulgan's ${ }^{24}$ and Narcy's ${ }^{25}$ ones may be considered more specific contributions, but in my opinion there is still so much to say.

What we know about Lycophron, therefore, comes from Aristotle who reports of him in five of his works: in the Metaphysics, in the Physics, in the Politics, in the Rhetoric, in the Sophistical Refutations. Aristotle thus recalls the name and ideas of Lycophron in different works citing him in relation with different contexts. There is therefore a first evidence to be accepted: from Aristotle's point of view, Lycophron is noteworthy, is interesting. Just think that Gorgias, a better known -at least to us- Sophist than Lycophron, is recalled by Aristotle only in the Rhetoric and in the Sophistical Refutations: ${ }^{26}$ Aristotle did not feel the urge to mention him in the Metaphysics or in the Politics or even in the Physics or else; Lycophron, however, is quoted in a wide range of works by Aristotle, and it shows the fact that Aristotle probably knew him well, knew the extent of his research, and thought him to be useful to the purpose of his treatises.

\section{On the ovvovoía}

The remove of the eighth book of Aristotle's Metaphysics (H. 61045 b 8) corresponds to the first fragment of section 83 of the Diels-Kranz collection dedicated to Lycophron; (83DKA1):

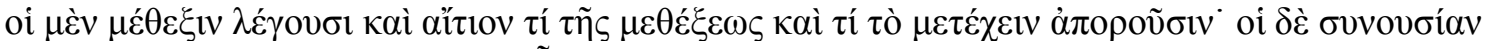

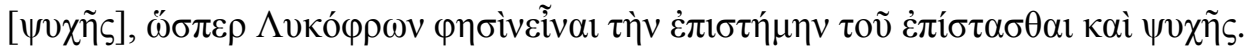

\footnotetext{
${ }^{24}$ Mulgan 1979.

${ }^{25}$ Narcy 2005.

${ }^{26}$ Of course not including the possible book about Gorgias that Aristotle seems to have written, according to the catalogue of his works in Diogenes Laertius, at least since it did not get to us and it remains within the sphere of virtuality; see D.L. V, 25.
} 
Some speak of participation and are perplexed as to what is the cause of the participation, and what "to participate" means. Others speak of "communion," as when Lycophron says that "knowledge is a communion of knowing and of soul."27

The text is then followed by Alexander of Aphrodisias' commentary on the same Metaphysics [Alex. Aphr. In metaph. 563, 32. - II 307. 15 App.]:

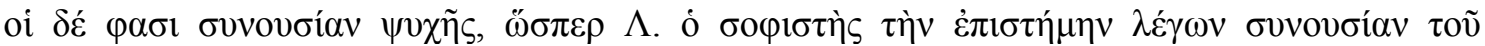

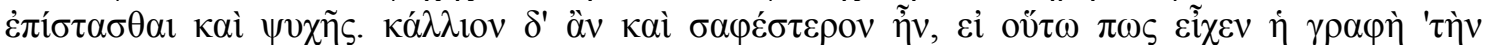

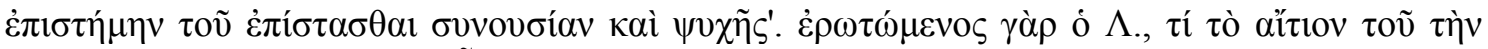

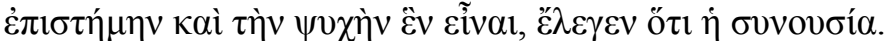

But some speak of a communion of soul, as when Lycophron the sophist says that knowledge is a communion of knowing and of soul. But it would have been better and clearer if the writing had run somewhat like this: "that knowledge is of knowing a communion and of soul." For when asked what was the cause of the unity of knowledge and the soul, Lycophron replied: "the communion."

In this passage of the Metaphysics Aristotle tackles the problem of the nature of knowledge $^{28}$ and is concentrated on reporting the Platonic theory of $\mu \varepsilon \dot{\varepsilon} \theta \varepsilon \xi 1 \varsigma$ (participation). In line with his method, before to discuss his own position Aristotle first shows the previous or contemporaneous theories to detect their limits or faults and somehow invalidate them, thus preparing adequate space to its solution. Aristotle's position is critical in regard to the Platonists' theory that supports participation. Aristotle adds that while the Platonists explain the possibility of knowledge as a participation of the physical world in the world of ideas, of the particulars in the forms, some have different positions, such as Lycophron for whom science $(\dot{\varepsilon} \pi \imath \tau \eta \dot{\mu} \mu \eta)$, i.e. scientific knowledge, is a communion of knowledge ( $\tau$ ó ė $\pi i ́ \sigma \tau \alpha \sigma \theta \alpha \imath)$ and soul ( $\psi v \chi \eta ́)$. In Lycophron appear as fundamental two elements that together generate knowledge in its highest degree, or science: these are knowledge and soul. Soul is also central in Plato: in fact, it plays a key role as it is the prerequisite to reminiscence, that act of remembering that is the result of the path the soul takes from one incarnation to the other and that gives the very soul the possibility to come in contact with the ideas in the Hyperuranium. The soul is nourished by the vision of ideas and falls reincarnating with that experience of innatism that will be critical to the performance of intellectual knowledge. The Platonic theory that binds the soul to the knowledge of ideas is definitely familiar. It is less known, however, the stance of Lycophron that Aristotle shows in this excerpt. What is, then, the stance of Lycophron that can be seen from this note of Aristotle? The answers the critical literature has given to this specific question, it will be weird, are definitely not exhaustive: probably because those studying Aristotle's Metaphysics have no real need to dwell on this step and on the other hand the studies on Lycophron, as it is said, are really scant. An analysis that can work as a counterpoint in our case is Bonazzi's one. In one of his books on the Sophists, he writes as a comment to this remove from Aristotle relating to the reconstruction of a gnoseology of Lycophron: "[...] la conoscenza dunque non si riduce all'affermazione che Socrate è bianco, ma si realizza nell'esperienza concreta e immediata della bianchezza di Socrate [...]." 29 I do not think that Lycophron here prospects knowledge as the result of the association of an empirical and concrete feeling,

\footnotetext{
${ }^{27}$ The english translation of Lycophron's fragments, based on DK edition, is by W. O’Neill in Kent Sprague 2001.

${ }^{28}$ Aristotle in Book VIII of the Metaphysics treats of the sensible substance in relation to actuality and potentiality and the unity of substance.

${ }^{29}$ Bonazzi 2010, 52.
} 
instead it seems to me that the issue is essentially another. In Lycophron the key terms, i.e. knowledge, communion and soul, can only interact in one way: the soul by knowing becomes the means through which we have - is produced - knowledge. The relationship between soul and knowledge is called by Lycophron "communion" ( $\sigma v v o v \sigma i ́ \alpha)$, but it is essentially a process analogous to that which allows the participation ( $\mu \varepsilon \dot{\varepsilon} \theta \varepsilon \xi 1 \varsigma)$. Lycophron uses a different language than Plato, of course, but in substance it does not differ that much. After all, the two positions are combined in their intention by the same Aristotle: he wants to discuss the union of actuality and potentiality and the inseparable unity of substance, and he gives examples to this purpose. In fact, he refers to the Platonists and Lycophron; he then moves to other areas with more examples to say that it is a mistake to seek the cause of the connection between potentiality and actuality, as everything is inseparable unity: he brings the example of life that is connection of soul and body, of feeling good that is connection of soul and health and of the bronze triangle that is connection of the triangle and bronze.

Aristotle therefore sees in Lycophron an alternative theory to the Platonic one, but, reading it in a proper way, almost exclusively from the lexical point of view. This leads us to think that Lycophron had a very broad store of knowledge on the Platonic themes and that he stood as a valuable alternative in a context in which, among other things, he could act relevantly.

\section{$X$ (is) $Y$}

Arist. Phys. A2. 185 b 25:

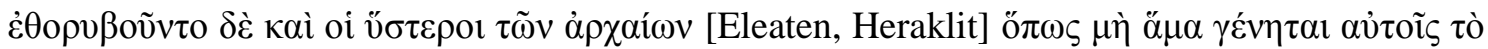

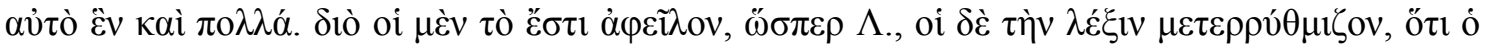

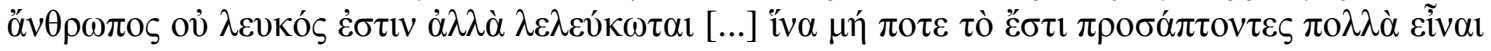
$\pi$ oı $\tilde{\sigma} \sigma \mathrm{l}$ ò हैv.

Even the more recent of the ancient thinkers [...] were troubled lest the same thing turn out for them, at the same time, one and many. So some, like Lycophron, removed the "is", while others changed the form of expression, to the effect not that man "is white" but "has been made white" [...] lest by the addition of the "is" they should make the one to be many.

In this step of the Physics, corresponding to the second fragment of DK, Aristotle treats the multiplication of entities. The pass is also included by Giannantoni in his $\mathrm{SSR}^{30}$ among the testimonies of Menedemus ${ }^{31}$. Aristotle argues that some thinkers have tried to solve the theoretical and ontological difficulty of the multiplication of entities through different solutions regarding the use and function of the verb 'to be'. Among these authors he cites Lycophron, who has foreseen a personal solution: eliminate the copula between the subject and its predication as to not create in this equivalence a third term that would cause the multitplication he seeks to avoid.

In this passage we could see a sophistic solution: indeed, it is an analysis that involves the language, and such language, its mechanisms and its operation have been the sophists' focus of speculation: just think of Hippias or Prodicus.

\footnotetext{
${ }^{30}$ Giananntoni 1990.

${ }^{31}$ Cf. The fragments on Menedemus of Eretria in Giannantoni 1990, III F 19 -20. Cf. also Movia 1991, 280

n. 85. Giannantoni does not only include the excerpt from Aristotle's Physics but also Simplicius (III F 19: in Aristot. phys. p. 91, 28-33 e in Aristot. categ. p. 216, 12-4) and Philoponus (III F 20: in Aristot. phys. p. 49, 18-21).
} 
But Aristotle's reference cannot only be considered as a reminder of the sophistical practices: it is much more complex in itself, and furthermore inserted in a discussion in which a recall to sophistry would be out of place. Even more: here we are facing a speculation that exceeds the linguistic dimension to enter the ontological. You might think that Lycophron follows in the footsteps of his alleged master Gorgias, who had

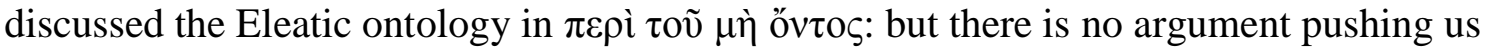
in this direction. One thing we can say is that Lycophron's reference, as it was also the Platonists' one, it is the Eleatic ontology.

Fait ${ }^{32}$ worked on paralogisms of identity in Aristotle and particularly on paralogisms depending on the accident that Aristotle treats in Sophistical Refutations. This scholar's analyses are particularly useful for the assessment of this remove of Physics. Fait stresses that a paralogism arises from the inability to distinguish between identity and predication. The issue had been raised by Plato in the Sophist in 251a5-c6. Plato attacked who he called "for old men whose learning has come to them late in life" (ö $\psi \mu \alpha \theta \varepsilon i \tilde{s} ;$ [...]

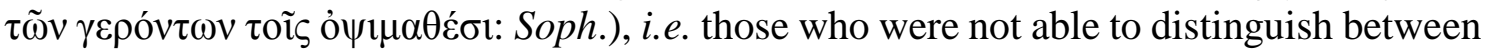
two uses of the verb 'to be'. Fait, in his essay, resembles the famous example of Frege to clarify the terms of the issue:

- the grass is green: predicative use of the verb 'to be'

- he is Alexander the Great: use of the identity of the verb 'to be' ${ }^{33}$.

Plato's ó $\psi \mu \alpha \theta \varepsilon i \tilde{\varsigma}$ admitted only tautological identity like ' $\mathrm{X}$ is $\mathrm{X}$ ' defined as $\mathrm{X}=\mathrm{X}$ and not other types of predication as ' $\mathrm{X}$ is $\mathrm{Y}$ ' defined as $\mathrm{X}=\mathrm{Y}$ because the latter type of predication could lead to a multiplication of entities. In the second case if $X$ is identified with Y, it will not only be $\mathrm{X}$ but also $\mathrm{Y}$ and therefore it will be multiplied. Who is Plato referring to as ó $\psi \mu \alpha \theta \varepsilon \tilde{\varepsilon} \varsigma$ ? For some Antisthenes ${ }^{34}$, as he feared the multiplication of entities as suggested by Aristotle in Metaphysics; ${ }^{35}$ but this possibility seems dispelled by the suggestions of Movia ${ }^{36}$, in line with Decleva Caizzi ${ }^{37}$, for whom Plato referred more easily to Sophistical and Megarian environments as Antisthenes did not support the theory for that only identical judgments are legitimate but only admitted "proper" judgements.

In the excerpt of Physics hereby analyzed, Aristotle exactly shows examples of authors who in the wake of Plato's ó $\psi \mu \alpha \theta \varepsilon i \bar{\varsigma}$ face the problem of the predication of the verb 'to be' and look for a solution to the use of copula: the solutions are to suppress the copula, as proposed by Lycophron, or even to replace the copula and the nominal part with a verb; this latter solution is attributed by Aristotle to other not directly identifiable authors that should match Eretrians and Megarians, hence Minor Socratics.

Bonazzi states that "la sua proposta [of Lycophron] è meno radicale di quanto non appaia da questo passo: il confronto con altre testimonianze più tarde, dai commentatori neoplatonici ad Aristotele, mostra che egli, per eliminare le ambiguità inerenti al doppio uso del verbo essere avrebbe proposto di abolire solo il senso predicativo, non quello esistenziale." 38 The 'later testimonies' are those Themistius ${ }^{39}$, Philoponus ${ }^{40}$ and

\footnotetext{
${ }^{32}$ Fait 2008.

${ }^{33}$ Fait 2008, 208 esp. n. 4.

34 Giannantoni considers Antisthenes an ỏ $\psi \mu \alpha \theta \eta \dot{\zeta}$ because he had learned the philosophy later: he had become a pupil of Socrates, having trained as a sophist and rhetorician with Gorgias; Cf. Giannantoni 198385, 204; and infra n. 4.

${ }^{35}$ Metaph. 1024 b 32.

${ }^{36}$ Cf. Movia 1991, 280 esp. n. 84 e n. 85.

${ }^{37}$ Decleva Caizzi 1966.

${ }^{38}$ Bonazzi 2010, 51.

${ }^{39}$ In Aristotelis metaphysicorum librum paraphrasis 6, 25-27, 2.

${ }^{40}$ in Ph. 43, 9-13.
} 
Simplicius ${ }^{41}$. I do not know how useful it is to rely on these sources to decide to accept that the elimination of copula in Lycophron was limited to its predicative usage and did not involve the existential usage. Among other things, the existential usage would be guaranteed by the admission of tautology ' $\mathrm{X}$ is $\mathrm{X}$ ' $(\mathrm{X}=\mathrm{X})$, already for Plato's "ö $\psi 1 \mu \alpha \theta \varepsilon i \tilde{\varsigma}$ ". Thus, the late sources do not generate a big innovation when compared to what we already know: they reiterate that Lycophron had proposed a solution to the problem of the multiplication of entities; that he was inserted in the wake of Plato's ơ $\psi \mu \alpha \theta \varepsilon \tilde{i} \varsigma$, that these ó $\psi \mu \alpha \theta \varepsilon i \tilde{\varsigma}$ seem converging towards the school of Megara or that of Eretria, that Lycophron could be an ỏ $\psi \mu \alpha \theta \varepsilon \tilde{\varepsilon} \varsigma$.

This quick conclusion is perhaps further supported by a note of an historiographical nature that emerges from this passage of Physics: Aristotle ranks Lycophron as among oi

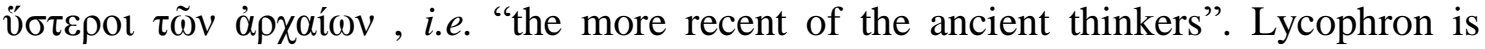
followed by those who proposed to convert the copula into verb through the noun phrase, i.e. presumably Eretrians and Megarians, thus authors who belong to minor Socratic schools.

The proximity to the Socratic schools that I think we can also observe in the content could have been advocated by Aristotle himself with this placement: the philosophers he refers to are among the last thinkers contiguous to him.

\section{Lycophron and the Social Contract}

Arist. Pol. Г 9. 1280 b 8:

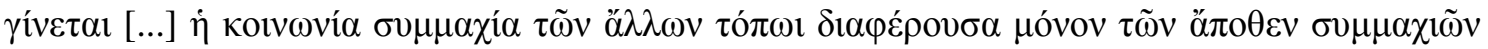

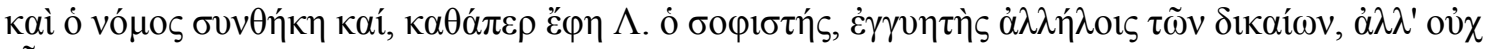

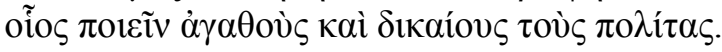

[...] the community becomes an alliance, differing only in location from the others sorts of alliance, where the members live at distance. And the law becomes a convention and, as Lycophron the sophist said, "a guarantor of mutual rights," but not such as to make the citizens good and just.

These lines of Aristotle's Politics are the reason why Lycophron is considered the first theorist of the social contract. Certainly he has contributed to the reflection on the contract, but the chronological aspects about if he was the first are yet to be evaluated. The theme, however, was well argued among the ancient thinkers, especially in those who made political thought an important part of their speculation, as the Sophists and even Plato. ${ }^{42}$

Among the Sophists, the idea of social contract that we can find is one of a contract between men ${ }^{43}$ of a conventionalistic kind. In fact, the contract is the product of a nonnatural dimension, chosen for necessity: the necessity arises from the fact that, without a covenant, men would tend to do wrong one another, while through an original pact they can define the laws that are the only guarantors of justice. Here we should place the theories of Antiphon and Hippias, but also a step of Plato's Republic (358th to 359th) where is Glaucon talking.

\footnotetext{
${ }^{41}$ in $\mathrm{Ph} .93,29-30$.

42 A review of ancient authors who have studied the social contract is in Mulgan 1979; see also Gough 1936 and Barker 1918.

${ }^{43}$ As we generally find in these ancient authors. A different conception is the contract conceived as a covenant between the governed and the governors as, for example, in the Laws of Plato (684a-b).
} 
Antiphon, in the fragments of his work On Truth $^{44}$, treats the social contract as a necessary pact: men would act according to their nature regardless of hurting others, and to avoid this unrestrained damage (primarily to not be damaged and be then victims of the abuse of others), they incur a pact that guarantees them their own lives and well-being.

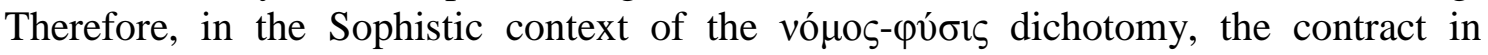
Antiphon is unnatural though necessary: unnatural as men, in freedom, would not care to harm others but only to follow their own needs. It is no coincidence that, as Antiphon emphasizes, when there are no witnesses men act without taking into account the laws but exclusively pursuing their own will. ${ }^{45}$ Even Hippias, about whom we are told by Xenophon ${ }^{46}$, inserts himself on the same arguments, reiterating the conventionality of the law; and also Glaucon ${ }^{47}$ in the aforementioned Platonic step expresses his idea of contract as a tool to prevent men doing wrong one another ${ }^{48}$.

About the contract in Plato, we need to take into account an important passage of the Crito, ${ }^{49}$ when Socrates decides to not escape death and to not disobey the laws because those are the result of the signing of a contract.

The fragment of Aristotle's Politics we are referring to is in the third book, when Aristotle is concentrated on addressing the characteristics of oligarchy and democracy, political systems which are not able to grasp the rights in their fullness. For Aristotle, a real worthy state should take care of virtue: only through virtue the community becomes an alliance. The alliance is more than a community, since it is based on virtue, on the same ethical reference. Alliances have this common feature, to be based on virtue, and that's why they are such wherever they are located. Hence, law is a convention ( $\sigma 0 v \theta \eta \dot{\kappa} \eta)$, that is an agreement based on virtue, made by men who pursue an ideal of allegiance.

To discuss the conventional aspect of law, Aristotle decides to use the words of

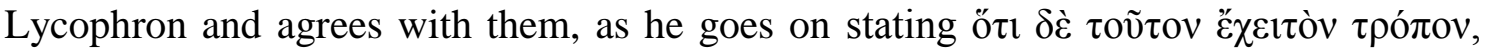

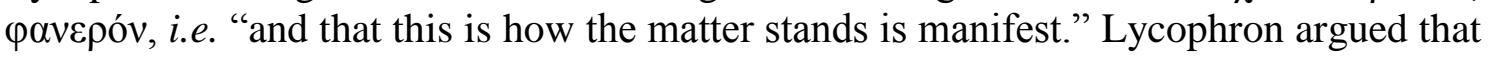
the law guarantees what is right between man and man: thus, the law is able to regulate relations between people on the basis of justice, but is unable to make these very same citizens good and just, is not able to change their nature. Hence, law is unable to act on the soul of men; and justice does not seem to have a correctional function, but rather a distribution one, in the sense that it does not pretend to change men but has the sole aim of granting the right to all men. ${ }^{50}$

Mulgan proposed an interpretation of this remove by Aristotle trying to redefine Lycophron's role in the history of social contract. Mulgan recognized how we traditionally think of social contract in a liberal sense, and this is also true in the case of

\footnotetext{
${ }^{44}$ DK87B44 (= P. Oxy. Pap. XI n.1364 ed. Hunt).

${ }^{45}$ DK87B44 [Col. 1, 1-33 Hunt]. On the law as against the nature cf. the speeches of Hippias in Prot. 337d and of Callicles in Grg. 484a-b.

${ }^{46}$ Mem. 4, 4, 13-14.

${ }^{47}$ On Glaucon cf. Vegetti 1998, esp. 161-162.

${ }^{48}$ Within this narrative it can suit the myth of the ring of Gyges, a ring capable of making who wears it invisible: a story that shows that those who practice the virtue would do so only when forced. On the historical Gyges and the Platonic myth, cf. Casertano 2010.

${ }^{49}$ Pl. Crit. 51d-52a; 52c-53c.

${ }^{50}$ Besides, it is not proper for the centuries V and IV to think that justice is corrective, the right also recalls us an idea of the law as not corrective but only punitive. We should remember that prisons were contemplated only to retain those who might flee before a process, not as a means for a positive reintegration into society; indeed, after a trial there were few expectations for those who were found guilty: according to the committed crime, the payment of a monetary penalty, the exile or the death sentence.
} 
Lycophron; the same goes for Popper ${ }^{51}$ and Guthrie ${ }^{52}$, who believed that the contract did not aim at applying the law, but at giving men the biggest freedom with respect to the law. According to Mulgan, Sophists as Antiphon and Hippias even overcame this liberal vision since they were hostile to positive law; the same goes for Glaucon in the Republic, for whom the contract, while conventional, is close to compromise. The idea that the social contract is an expression of liberal will is taken for granted by Aristotle himself, but Mulgan believes that Aristotle himself has been misled: Lycophron would not be a supporter of social contract as the minimum infuence of the law in the life of men. The hermeneutic tension in Mulgan is, however, too high: Aristotle is a reliable source, as Guthrie $^{53}$ claimed, and the text does not seems so obscure. I think that Mulgan was also limited by a mistaken explanation of Lycophron: his problem arises from believing Lycophron as Sophist. Aristotle didn't got wrong, he only didn't consider Lycophron as a Sophist.

The question we must ask is the nature of Lycophron's thesis. It appears permeated with a pragmatic spirit: in fact, Lycophron believes that the contract has a very specific purpose, i.e. to be a guarantor for men. Here Lycophron apparently seems to feed the

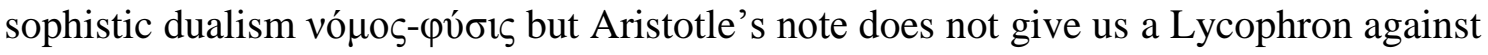
the positive law nor an advocate of criticism towards the same contract: it seems very noteworthy that Aristotle himself agrees with him, with his pragmatism. Law is not able to make men good but it does not mean that the law cannot be a human product: man is basically and instinct and rationality. This applies to Aristotle, and it is possible that this reflection is not completely alien to Lycophron. So what we can notice is that Lycophron's stance, whether shared to some extent by Aristotle or not, can be an alternative to other proposals, perhaps even to the Platonic one.

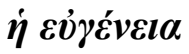

Arist. fr. 91 Rose [Stob. flor. IV 29 p. 710]:

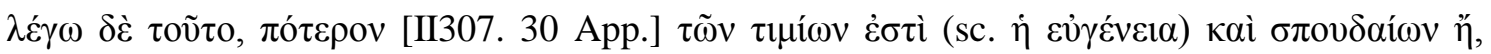

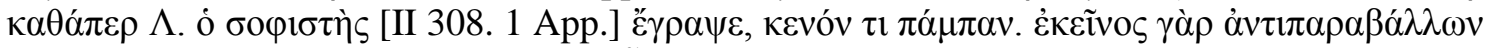

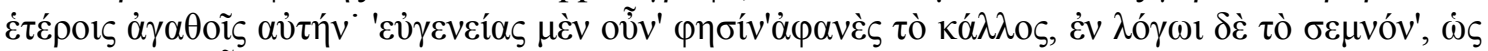

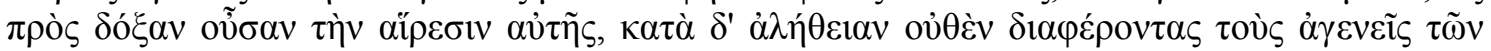

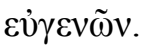

What i mean is this: Is [good birth] something valuable and worthwhile or, as Lycophron the sophist wrote, something altogether whortless? Comparing it with other goods he asserts: "Now the nobility of good birth is obscure, and its grandeur a matter of words," on the grounds that preference for it looks to opinion, whereas in fact there is no difference between the ignoble and the well-born.

\footnotetext{
${ }^{51}$ Popper uses the term "protectionism" to mean a contract that protects those who pledge it: «[...] It emerges clearly from Aristotle's context that Lycophron's theory was solely concerned with the end of the state; for Aristotle argues that Lycophron has not seen that th essential end of the state is to make its citizens virtuous. This indicates that Lycophron interpreted this end rationally, from a technological point of view, adopting the demands of equalitarism, individualism, and protectionism;» cf. Popper 1947, 100; see Chapter 6, esp. 100 and ss.

${ }^{52}$ Guthrie notes how the first idea of restriction through law as mutual defense among men comes from Hippodamus of Miletus (in Arist. Pol. II, 8), cf. Guthrie 1971, 139.

${ }^{53}$ Guthrie 1979: «It is simply a question of whether one believes Aristotle or not. I am inclined to think that he knew more about Lycophron than we do.»
} 
This passage of Aristotle is one of Rose's fragments from Joannes Stobaeus' Florilegium, fr. 91, included in the DK as the fourth excerpt: it is a passage from the dialogue $O n$

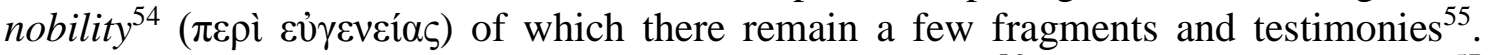
Aristotle had dealt with nobility in a remove of the Rethoric ${ }^{56}$ and in one of the Politics. ${ }^{57}$ Aristotle placed his reflections on nobility in a broad context, as the subject was known and discussed among the Greeks: in fact, it concerned Democritus ${ }^{58}$, Gorgias ${ }^{59}$, Critias $^{60}$, Plato $^{61}$ and Antisthenes. ${ }^{62}$

In fragment 91R we are analyzing Aristotle says that the theme of nobility is treated both

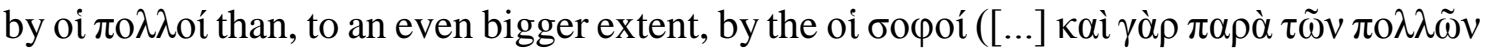

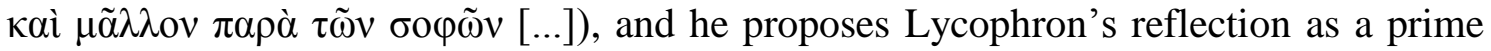
example, that is a perspective of those considered the major ones. In the collection of the fragments useful to the reconstruction of Aristotle's dialogue On nobility, fr. 91 is followed by fragments Rose 92, 93 and 94, where Aristotle brings Socrates, Simonides, Theognis ed Euripides as examples or considerable $\varepsilon^{\prime} v \delta o \xi \alpha$. So this Lycophron should have had some importance, if you find him along with these great intellectuals in the discussion On nobility. All this takes us to say that Aristotle knew Lycophron's thought well, as well as his possible production in point. We also know that Lycophron has been cited by ps-Plutarch in Pro Nobilitate ${ }^{63}$, where he treats Aristotle's works. Ps-Plutarch reports the excerpts, that later became fr. 91 and 92 Rose, and introduces them with these words: «Philo autem nobilitati non tam iniquus fuit quam putas, neque vero probavit Lycophronis sententiam tametsi retulerit.» ${ }^{64}$ The fact that the ps-Plutarch addresses to Lycophron is very significant: Lycophron appears as a valid interlocutor on the theme of nobility. Perhaps it would be too risky to deem him as an inescapable one, but surely he was a not negligible one.

Lycophron is a detractor of nobility, a dissenter of the aristocratic stance: he did not recognize a real value in the nobility of birth ( $\dot{\eta} \varepsilon \hat{\gamma} \gamma \varepsilon \dot{v} \varepsilon 1 \alpha)$, even from the social point of view. This could be coherent with the general Sophistic controversy against the aristocratic order: a not homogeneous controversy but rich in different positions; just look at the different attitude of Antiphon or Critias. For Lycophron, as Aristotle states, nobility is only one word: strength, beauty and splendor of nobility only reside in the word, that

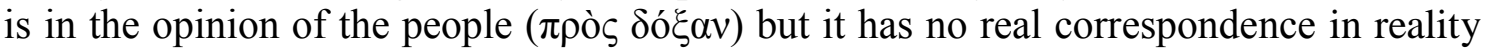

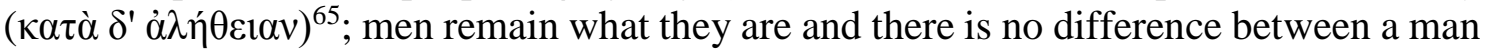
who is noble and one that is not. So, where the Sophistic principle for which the word is able to change reality is? Where is the teaching of Lycophron's alleged teacher Gorgias,

\footnotetext{
54 For an analysis of the concept of nobility in Aristotle cf. Zanatta 2008, 359-387 and Aouad et alii 1989, 454 ss.

${ }^{55}$ In addition to the fr. 91 Rose, to the frr. 92 and 94 Rose (from Stobeus), also fr. 93 Rose = D.L., II, 5, 26 (10); Plut. Aristid. XXVII, 2; Ath., XIII, 555d-556a.

${ }^{56}$ Rhet. II, 15, 1390 b 21.

${ }^{57}$ Pol. III, 13, 1283 a 36-37.

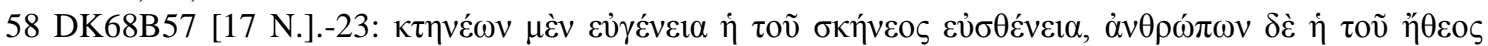

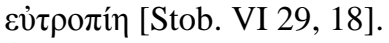

${ }^{59}$ DK82B11 - Encomium of Helen $§ 3-4$.

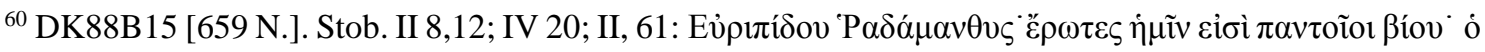

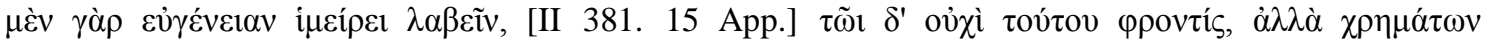

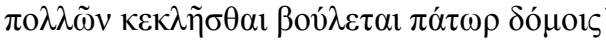

${ }^{61}$ Pl. Mx. 237b ss; Chrm. 155a 157e; Alc. I, 120 a ss.

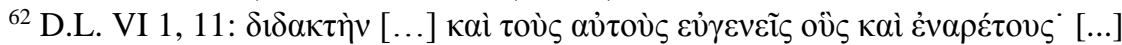

${ }^{63}$ Nob. 18.

${ }^{64}$ Cf. Zanatta 2008, 370 n. 7.

${ }^{65}$ Cf. Zanatta 2008, 373 n. 12.
} 
who had made the power of the word one of the key points of his arguments? ${ }^{66}$ Now, if we want to be down-to-earth, we know that in their argumentation all of our authors, including Gorgias, could argue against their very own theories simply out of necessity and then from my point of view it should be problematic to think that here the Sophistic principle would not be complied with. But the mistake, I think, is, once again, in the will to necessarily treat Lycophron as a Sophist: this attempt always recalls a comparison that is not that significant in itself, if not sterile at all.

So what is left of this fragment about Lycophron is tied exclusively to what we can see and not to what we can guess through the lenses of Sophistry.

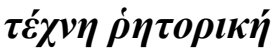

\section{Arist. Г 3. 1405b 34:}

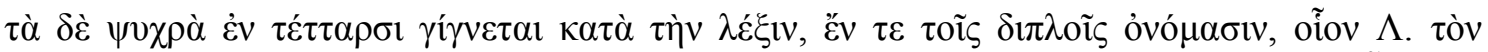

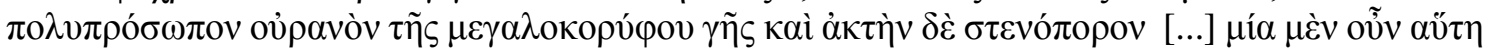

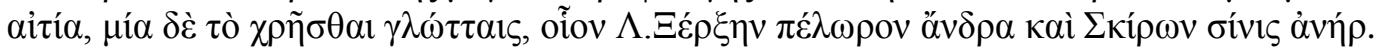

Insipid expressions occur in four cases: in compoud words, as when Lycophron speaks of "the many-visaged sky of the mighty-peaked earth" and "the narrow-passaged promontory." [...] now this is one cause of dullness, and another is the use of strange expressions, as when Lycophron calls Xerxes "a monster of a man," and Sciron "a human destroyer."

and

Arist. Soph. el. 15.174 b 32:

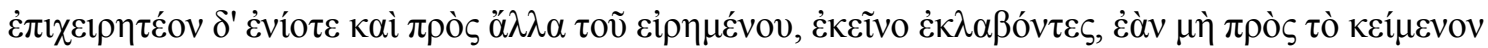

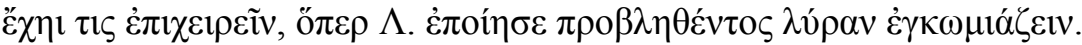

Sometimes also one should attempt points other than the one mentioned, taking it in a different sense, if one has no reply to make to the topic under discussion, as Lycophron did when it was proposed that he praise the lyre.

Alex. Aphr. ad loc. 118, 31 (nach einer falschen Erklärung) [II 308. 15]:

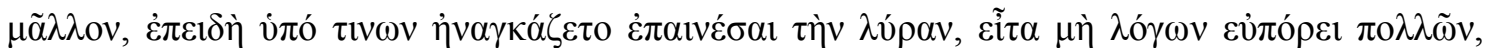

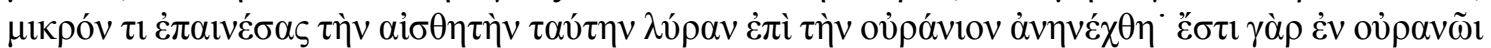

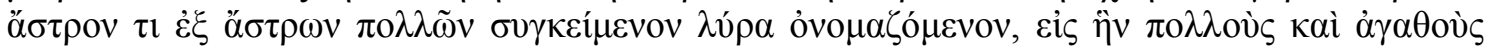

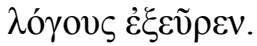

[according to a false interpretation ${ }^{67}$ ] or rather, when he was constrained by certain persons to praise the lyre, and then found himself at a loss for many words, he praised this tangible lyre for a little and then referred to the heavenly one; for there is in the heavens a costellation composed of many stars which is called the Lyre. On this subject he found many good things to say.

The two fragments we have approached here can be ascribed to the subject of rhetoric and respectively correspond to DK83A5-6.

We referred to the first one at the beginning of this study, and it is a testimony about the style of Lycophron: the use of compound words that Aristotle considered as a cause of coldness of the style but also a source of pleasure. I will not get back to the content but I

\footnotetext{
${ }^{66}$ See Gorgias, Hel. 8 (DK82b11); Protagoras, DK80B6b; see also Pl. Apol. 18b.

${ }^{67}$ i.e. from german, 'according to a false explanation.'
} 
state that, that according to Aristotle, Lycophron had an accurate prose in terms of rhetorics and somehow was an example to point out.

In the second fragment, we instead face the presentation of a rhetorical-argumentative technique: for Lycophron rhetoric is the ability to change the subject when the object that has to be discussed is not particularly inspiring. The strategy you can use when you have to develop a weak argument is to treat a similar argument. Here Aristotle gives the example of the lyre. Lycophron, called to stand a praise of the lyre and obviously having a few concepts to cling to, would have moved from talking about the lyre as a tool to treat the lyre as a constellation. This way, evidently, he could have a bigger argumentation. Here the weak argument is made strong by the loophole-argument. It should be note that Untersteiner held the information of the ps-Alexander uncertain because confusing and ambiguous: in fact firstly Lycophron wanted to praise the lyrists, then he would move the praise to the lyre, and later to the constellation. ${ }^{68}$

The value of this Aristotelian testimony is as always high, but not exactly identifying: Aristotle tells us that Lycophron knew how to use the words, to argue even when he could be in trouble for lack of arguments but does not tell us that Lycophron was a Sophist, belonging to the Sophistical movement as a direct pupil of one of the Major Sophists. It was not necessary to be sophists in order to understand rhetorics: or at least he could have learned the useful notions of rhetoric without undertaking a "career" as a sophist.

\section{Lycophron as a minor socratic}

The Aristotelian testimonies, albeit scarce, have been able to give us a general idea on this intellectual.

There is something binding these fragments and these testimonies together. In fact, overlooking the fragments on the rhetoric that in this context are less relevant, the others oscillating between ontology and politics are all led on the one hand by rational elaboration and on the other by some pragmatic spirit: Lycophron seems pragmatismoriented both in ethics and in the field of ontology language.

Of course it is all about looking for a logical thread around the thought of an unknown author about which a rightful doubt stays behind.

If we want to determine which current or which school we can ascribe this intellectual to doubts increase as also do risks. Zeller in his times and, later, Diels have done this: they took a risk and established a canon, which has been the locus communis for the entire scientific community. They established with as much plausible evidence for them as possible that Licophron was a Sophist, pupil of Gorgias, thus a Minor Sophist who took by his teacher subjects and argument capability.

I believe that the scientific community has not only relied on this canon, but somehow rested on it: it accepted such an interpretation without asking too much, and this is also due to the fact that the author has been little studied except for his position on the matter of the social contract. But I think that today it is worth reviewing this commonplace, even at the cost of losing certainties instead of acquiring them.

Let's summarize what information is actually available:

- Licophron was able to treat ontology, and this required a good knowledge of Parmenidism;

- Licophron took a stance about the problem of the multiplication of entities born within the Platonic theory. His theory of the elimination of the copula can be seen as an

\footnotetext{
${ }^{68}$ Untersteiner 2009, 351 n.6.
} 
opposition to the outcomes of Platonism, an alternative to Platonic thought; here his theory looks associated to the Megarians' ones.

- Licophron was interested in politics and has developed a theory of contract

- In his thought it can be noticed at some point an adherence to some Sophistical practices, although general and not particularly indicative

- He is a relevant author for Aristotle but not for Plato, in whose work there is no trace of neither the character nor his theory.

The idea that I have developed is that Lycophron probably knew the Sophists, perhaps even Gorgias, also listened to their lessons but then engaged in the Socratic milieu, becoming one of the many alter egos of platonism. Kind of Antisthenes. Antisthenes, after

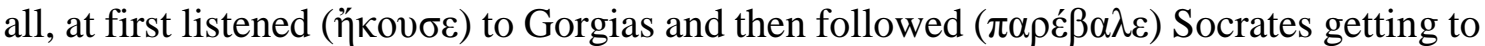
a stance that was alternative to Platonism. ${ }^{69}$ This may also partly explain why Plato $^{70}$ has been silent about Lycophron while Aristotle held him in such an high regard.

Therefore, I mean to answer the question that gives this study its title: in my humble opinion, Lycophron is not a Minor Sophist, he was more likely a minor Socratic (perhaps a Megarian ${ }^{71}$ ?). He took advantage of the cultural background of Sophistry (and who, also among the Megarians, at the time has not benefited from it?) but then got on a different path, maybe more philosophically complex, getting into Socratism and alternatives to Platonism. Moreover, the Socratic schools, in their heterogeneity, absorbed the previous thought in many ways and also took advantage of the Sophistic background, reviewing the Platonic thought starting from what they considered as errors or distortions of the system. Their interests, nonetheless heterogeneous, moved among ontology, ethics, gnoseology and logic.

Even if this argument might seem tenuous, I believe that it may currently be the best solution for a reading of the testimonials as a whole. In any case, its weakness cannot be much bigger than the one of the traditional locus communis.

\section{Bibliography}

Aouad et alii 1989 - M. Aouad et alii, Aristote de Stagire, in Dictionnaire des Philosophes Antiques, publié sous la direction de R. Goulet, I 414, CNRS Editions, Paris, 413-590.

Baeumker 1879 - C. Baeumker, Über den Sophystes Polixenos, «Rheinisches Museum», XXXIV, 64-83

Barker 1918 - E. Barker, Greek Political Theory. Plato and his Predecessors, University Paperbacks, London-New York

Boehnecke 1864 - R.G. Boehnecke, Demosthenes, Lycurgos, Hyperides und ihr Zeitalter, mit Benutzung der neuesten Entdeckungen, vornehmlich griechischer Inschriften, I, Berlin

Bonazzi 2007 - M. Bonazzi (ed.), I sofisti, Bur, Milano

Bonazzi 2010 - M. Bonazzi, I sofisti, Carocci Editore, Roma

Casertano 2010 - G. Casertano, La regina, l'anello, la necessità, in Giombini-Marcacci 2010, 587-599

Decleva Caizzi 1966 - F. Decleva Caizzi, Antisthenis Fragmenta, Istituto Editoriale Cisalpino, Milano-Varese

\footnotetext{
${ }^{69}$ D.L. VI, 1: Oṽ̃

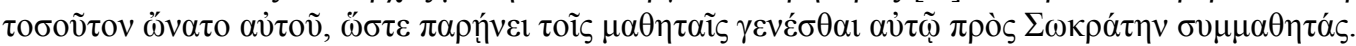

${ }^{70}$ Plato is also silent on Antisthenes, except for a passage of Phaedo in which he cites who was with Socrates the day of his death; vd Phd. 59b.

${ }^{71}$ For the affinity of reasoning and including the sophistic influence, the reelaboration of Parmenides' doctrine, the interest in logic and in ethic. On Megarian school cf. Zilioli 2014.
} 
Fait 2008 - P. Fait, Aristotele e i paralogismi dell'identità, «Rivista di storia della filosofia», n. 2, 205-226

Findlay 1994 - J. N. Findlay, Plato. The written and unwritten doctrines, Humanities Press, New

York 1974 (Routledge Revivals, London 2013); italian ed., Platone. Le dottrine scritte e non scritte, Vita e pensiero, Milano 1994.

Gagarin 2002 - M. Gagarin, Antiphon the Athenian. Oratory, Law, and Justice in the Age of the Sophists, University of Texas Press, Austin

Giannantoni 1983-85 - G. Giannantoni, Socratis et Socraticorum Reliquiae, collegit, disposuit, apparatibus notisque instruxit Gabriele Giannantoni, 4 voll., Bibliopolis, Napoli $\left(1990^{2}\right)$

Giombini-Marcacci 2010 - S. Giombini-F. Marcacci, Il V secolo. Studi di filosofia antica in onore di Livio Rossetti, Aguaplano-Officina del Libro, Passignano s. T.

Gough 1936 - J. W. Gough, The Social Contract. A Critical Study of its Developments, Oxford University Press, London

Guthrie 1971 - W.K.C. Guthrie, The Sophists, Cambridge University Press, Cambridge

Guthrie 1979 - W.K.C. Guthrie, Reply to R. G. Mulgan, «Journal of History of Ideas», XL, 128

Kennedy 2007 - G.A. Kennedy (ed.), Aristotle, On Rhetoric. A Theory of Civic Discourse, Translated with Introduction, Notes, and Appendices by G. A. Kennedy, Oxford University Press, New York-Oxford

Kent Sprague 2001 - R. Kent Sprague (ed.), The older Sophists. A complete translation by several hands of the fragments in Die Fragmente der Vorsokratiker edited by Diels-Kranz, with a new edition of Antiphon and of Euthydemus, Hackett Publishing Company, Indianapolis-Cambridge

Movia 1991 - G. Movia, Apparenze, essere e verità. Commento storico-filosofico al "Sofista" di Platone, Vita e Pensiero, Milano

Mulgan 1979 - R.G. Mulgan, Lycophron and Greek Theories of Social Contract, «Journal of History of Ideas», XL (1979), 121-128

Narcy 2005 - M. Narcy, v. Lycophron, R. Goulet (ed.), Dictionnaire des philosophes antiques IV, CNRS Editions, Paris, 203-205.

Popper 1947 - K.R. Popper, The Open Socitey and its Enemies, vol. 1, The Spell of Plato, Routledge, London

Untersteiner 2009 - M. Untersteiner, Sofisti. Testimonianze e frammenti, Bompiani, Milano

Vahlen 1866 - J. Vahlen, Der Sophist Lykophron, «Rheinisches Museum für Philologie», Neue Folge, 21. Jahrg. (1866), 143-146.

Vegetti 1998- M.Vegetti, Glaucone, in M. Vegetti (ed.), Platone. La Repubblica, vol. II, pp. 151172, Bibliopolis, Napoli

Vlastos 1954 - G. Vlastos, The Thrid Man Argument in the Parmenides, «The Philosophical Review» 63, 3, 319-349

Vlastos1973 - G. Vlastos, Platonic Studies, Princeton University Press, Princeton

Zanatta 2008 - M. Zanatta (ed.), Aristotele. I dialoghi, BUR, Milano

Zeller 1881 - E. Zeller, A History of Greek Philosophy. Vol. II. From the Earliest Period to the Time of Socrates, translated by S.F. Alleyne, Longmans, Green and Co., London

Zilioli 2014 - U. Zilioli, The Circle of Megara, Acumen Publishing 